\title{
PENERAPAN METODE PROFILE MATCHING UNTUK MENENTUKAN PREDIKAT SALESMAN TERBAIK
}

\author{
Titin Kristiana \\ Program Studi Sistem Informasi Fakultas Teknologi Informasi \\ Universitas Bina Sarana Infromatika \\ Jl Kamal Raya No.18 Ringroad Barat Cengkareng Jakarta Barat \\ Email : titin.tka@bsi.ac.id
}

\begin{abstract}
Selecting the best salesman in a company is not all objekif. Where the determination of the public saw only a salesman. In this case to determine suitable candidates with the necessary requirements of a decision support system. This study uses a profile matching methods in decision support systems. The criteria used in decision support systems are the Best Salesman assessment: Ability, Personality, and Knowledge Against Salesman Company. Data values are obtained directly calculated using the formula contained in the profile matching method. Results from this study resulted in the order of ranking of candidates Salesman best and output of the results of the study can help the Sales Manager for the decision making process to determine the Best Salesman Predicate
\end{abstract}

\begin{abstract}
Abstrak - Pemilihan salesman terbaik dalam suatu perusahaan belum semuanya objekif. Dimana penentuannya hanya melihat dari sisi umum seorang salesman. Dalam hal ini untuk menentukan kandidat yang sesuai dengan kebutuhan diperlukan suatu sistem pendukung keputusan. Penelitian ini menggunakan metode profile matching dalam sistem pendukung keputusan. Kriteria yang digunakan pada sistem pendukung keputusan penilaian Salesman Terbaik ini adalah : Kemampuan, Kepribadian, serta Pengetahuan Salesman Terhadap Perusahaan. Data nilai yang diperoleh langsung dihitung menggunakan rumus-rumus yang terdapat dalam metode profile matching. Hasil dari penelitian ini menghasilkan urutan rangking dari calon Salesman yang terbaik dan output dari hasil penelitian tersebut dapat membantu para Sales Manager untuk proses pengambilan keputusan dalam menentukan Predikat Salesman Terbaik
\end{abstract}

\section{Pendahuluan}

Keberhasilan dari sebuah perusahaan distributor yang besar tidak lepas dari peran serta seorang salesman yang menjadi ujung tombak di dalamnya. Salesman berperan penting dalam perusahaan distributor, seorang salesman dapat meningkatkan penjualan serta penambahan keuntungan sebuah perusahaan. Semakin banyak penjualan barang yang dilakukan salesman maka semakin banyak keuntungan yang didapat perusahaan. Hal tersebut terjadi karena kemampuan yang dimiliki seorang salesman yang dapat berinteraksi langsung dengan pembeli dan meyakinkan pembeli untuk memesan ataupun membeli barang.

Penerapan sistem pendukung keputusan dengan metode profile matching dilakukan dalam menentukan sales terbaik yang akan dipromosikan menjadi sales manajer[1]. Sistem pendukung keputusan untuk menentukan karyawan manakah yang memiliki prioritas untuk mendapatkan gaji berdasarkan dengan kinerja dan produktivitasnya serta dapat menentukkan besarnya bonus yang pantas untuk diterima salesman tersebut. Sistem pendukung keputusan ini juga dapat berguna untuk memonitor kinerja salesman dari waktu ke waktu. Sistem ini juga dapat digunakan sebagai acuan dalam penentuan langkah selanjutnya bagi salesman yang berprestasi maupun tidak [2].Profile Matching dapat membantu proses mekanisme perhitungan kriteria dalam pengambilan keputusan terhadap suatu objek yang dinilai dan dilihat dari tingkat variabel prediktor yang ideal yang harus dimiliki calon karyawan tetap.[3] Pemilihan vendor adalah permasalahan multi kriteria dimana setiap kriteria yang digunakan mempunyai kepentingan yang berbeda dan informasi mengenai hal tersebut tidak diketahui secara tepat [4]

Jika kita melihat dari segi umum kemampuan yang dimiliki seorang salesman dengan salesman lainnya hampir sama atau tidak jauh berbeda, hal ini membuat pimpinan perusahaan menjadi sulit untuk menentukan predikat salesman terbaik. Proses penilaian pun menjadi lebih rumit dan membuang waktu yang lama, selain itu terkadang penilaian pun tidak mencakup ke semua kategori, namun hanya melihat dari kategori secara umumnya, dan proses penilaian pun menjadi belum akurat. Hal ini membuat adanya kesenjangan sosial diantara para salesman

Penelitian ini dapat membantu pimpinan perusahaan agar dapat menentukan predikat salesman terbaik dengan akurat dan tidak terjadi kesenjangan sosial diantara para salesman, proses penilaian pun dilakukan dengan melihat kemampuan salesman secara keseluruhan, dan dibuat perkategori sehingga hasil penelitian ini dapat akurat dan efektif dalam proses penentuan predikat salesman terbaik 
Metode yang akan digunakan dalam pengambilan keputusan ini adalah metode Profile Matching. Hal ini dikarenakan metode Profile Matching menghitung dengan cara selisih nilai yang akan dimasukan kedalam rumus-rumus dalam metode ini. Dari nilai yang dihasilkan akan didapat peringkat-peringkat

\subsection{Identifikasi Masalah}

Untuk mempermudah pembahasan ini, maka penulis meng-identifikasi masalah sebagai berikut:

1. Bagaimana menentukan predikat salesman terbaik menggunakan sistem pendukung keputusan dengan metode profile matching

2. Bagaimana cara menentukan predikat salesman terbaik lebih akurat dan obyektif

3. Bagaimana cara untuk membuat sistem pendukung keputusan yang membantu untuk menentukan predikat salesman terbaik, menentukan nilai bobot variabel, dan menentukan nilai gap dari nilai yang telah didapat dari pimpinan

\subsection{Tujuan}

Tujuan dari penelitian ini adalah untuk mengetahui proses penilaian predikat salesman terbaik dengan kriteria yang telah ditentukan. Menerapkan metode Profile Matching sebagai metode Sistem Pendukung Keputusan (SPK) dalam penilaian karyawan, serta menentukan nilai gab dari nilai yang telah didapat dari pimpinan, sehingga membuat transparasi penilaian terhadap salesman.

\section{Metode Penelitian}

\subsection{Sistem Pendukung Keputusan / Decision Support System (DSS)}

Menurut Alter dalam Kusrini [5] menyimpulkan bahwa " $D S S$ merupakan sistem informasi interaktif yang menyediakan informasi, pemodelan, dan pemanipulasian data. Sistem ini digunakan untuk membantu pengampilan keputusan dalam situasi yang semi terstruktur dan situasi yang tidak terstruktur, dimana tak seorang pun tahu secara pasti bagaimana keputusan seharusnya dibuat".

\subsection{Profile Matching}

Menurut Kusrini [5] berpendapat bahwa "Maksud dari pencocokan profil (profile matching) adalah sebuah mekanisme pengambilan keputusan dengan mengasumsikan bahwa terdapat tingkat variabel prediktor yang ideal yang harus dimiliki oleh pelamar, bukannya tingkat minimal yang harus dipenuhi atau dilewati".

Dalam profile matching, dilakukan identifikasi terhadap kelompok karyawan yang baik maupun buruk. Para karyawan dalam kelompok tersebut diukur menggunakan beberapa kriteria penilaian. Jikalau pelakasana yang baik memperoleh skor yang berbeda dari pelaksana yang buruk atau sebuah karakteristik, maka variabel tersebut berfaedah untuk memilih pelaksana yang baik.[5]

\section{Pemetaan GAP}

Gap yang dimaksud disini adalah "perbedaan antara profil karyawan dengan profil Jabatan atau bisa ditunjukkan pada rumus dibawah ini” :

$$
\text { Gap = Profil Karyawan }- \text { Profil Jabatan }
$$

\section{Pembobotan GAP}

"Setelah diperoleh gap pada masing-masing pegawai, setiap profil pegawai diberi bobot nilai dengan patokan tabel bobot nilai gap. Seperti yang terlihat pada tabel dibawah ini":

Tabel.1

Tabel Bobot Nilai Gap

\begin{tabular}{|c|c|c|l|}
\hline No & Selisih & $\begin{array}{c}\text { Bobot } \\
\text { Nilai }\end{array}$ & \multicolumn{1}{|c|}{ Keterangan } \\
\hline 1 & 0 & 5 & $\begin{array}{l}\text { Tidak ada selisih (Kompetensi } \\
\text { sesuai dengan yang dibutuhkan }\end{array}$ \\
\hline 2 & 1 & 4,5 & $\begin{array}{l}\text { Kompetensi individu kelebihan } \\
1 \text { tingkat/level }\end{array}$ \\
\hline 3 & -1 & 4 & $\begin{array}{l}\text { Kompetensi individu } \\
\text { kekurangan 1 tingkat/level }\end{array}$ \\
\hline 4 & 2 & 3,5 & $\begin{array}{l}\text { Kompetensi individu kelebihan } \\
2 \text { tingkat/level }\end{array}$ \\
\hline 5 & -2 & 3 & $\begin{array}{l}\text { Kompetensi individu } \\
\text { kekurangan 2 tingkat/level }\end{array}$ \\
\hline 6 & 3 & 2,5 & $\begin{array}{l}\text { Kompetensi individu kelebihan } \\
3 \text { tingkat/level }\end{array}$ \\
\hline 7 & -3 & 2 & $\begin{array}{l}\text { Kompetensi individu } \\
\text { kekurangan 3 tingkat/level }\end{array}$ \\
\hline 8 & 4 & 1,5 & $\begin{array}{l}\text { Kompetensi individu kelebihan } \\
4 \text { tingkat/level }\end{array}$ \\
\hline 9 & -4 & 1 & $\begin{array}{l}\text { Kompetensi individu } \\
\text { kekurangan 4 tingkat/level }\end{array}$ \\
\hline
\end{tabular}

1. Perhitungan dan Pengelompokan Core Factor dan Secondary Factor

Setelah menentukan bobot nilai gap untuk setiap aspek, kemudian setiap aspek dikelompokan menjadi 2 kelompok, yaitu kelompok Core Factor dan Secondary Factor. Pengelompokan core factor ditunjukkan menggunakan rumus dibawah ini.

$$
N C F=\frac{\sum N C}{\sum I C}
$$

Keterangan :

$N C F$ : Nilai rata-rata core factor 


\section{NC : Jumlah total nilai core factor \\ IC : Jumlah item core factor}

Sementara itu, perhitungan secondary factor bisa ditunjukkan dengan rumus berikut:

$$
N S F=\frac{\sum N S}{\sum I S}
$$

Keterangan :

$$
\begin{array}{ll}
N S F & \text { : Nilai rata-rata secondary factor } \\
N S & \text { : Jumlah total nilai secondary factor } \\
I S & \text { : Jumlah item secondary facto }
\end{array}
$$

\section{Perhitungan Nilai Total}

"Dari hasil perhitungan setiap aspek, berikutnya dihitung nilai total berdasarkan persentase dari core dan secondary yang diperkirakan berpengaruh terhadap kinerja tiap-tiap profil. Penghitungan bisa dilihat pada rumus dibawah ini":

$$
N=(x) \% N C F+(x) \% N S F
$$

Keterangan :

$N \quad$ : Nilai Total dari aspek

$(x) \%$ : Nilai Persen yang diinputkan

NCF : Nilai rata-rata Core Factor

NSF : Nilai rata-rata Secondary Factor
3. Perhitungan Penentuan Ranking

Hasil akhir dari proses profile matching adalah "ranking dari kandidat. Penentuan ranking mengacu pada hasil perhitungan tertentu dengan aspek yang dicontohkan. Contoh perhitungan tersebut bisa ditunjukkan dengan rumus di bawah ini":

$$
\text { Ranking }=(x) \% N i+(x) \% N s+(x) \% N p
$$

Keterangan :

$\mathrm{Ni}$ : Nilai kapasitas intelektual

$N s$ : Nilai sikap kerja

$N p$ : Nilai perilaku

$(x) \%$ : Nilai Persen yang diinputkan

Setelah kandidat mendapat hasil akhir, maka bisa ditentukan peringkat atau ranking dari kandidat berdasarkan pada semakin besarnya nilai hasil akhir sehingga semakin besar pula kesempatan untuk menduduki peringkat teratas, begitu pula sebaliknya

\begin{tabular}{|c|c|c|c|c|c|c|c|c|c|c|c|c|}
\hline \multirow[b]{2}{*}{ No. } & \multirow{2}{*}{$\begin{array}{c}\text { Nama } \\
\text { Salesman }\end{array}$} & \multicolumn{11}{|c|}{ Variabel } \\
\hline & & M001 & M002 & M003 & M004 & M005 & M006 & M007 & M008 & M009 & \multicolumn{2}{|c|}{ GAP } \\
\hline 1 & Ahamd Fauzi & 4 & 4 & 5 & 5 & 3 & 3 & 4 & 4 & 3 & & \\
\hline 2 & Bambang Eb & 4 & 4 & 5 & 5 & 3 & 3 & 5 & 4 & 5 & & \\
\hline 3 & $\begin{array}{l}\text { Ahmad Nur } \\
\text { Sahid }\end{array}$ & 4 & 4 & 5 & 5 & 3 & 4 & 4 & 4 & 3 & & \\
\hline 4 & Adi Mulyono & 4 & 3 & 3 & 4 & 4 & 5 & 5 & 4 & 4 & & \\
\hline 5 & $\begin{array}{l}\text { Asep } \\
\text { Awaludin }\end{array}$ & 4 & 4 & 5 & 4 & 4 & 3 & 3 & 3 & 4 & & \\
\hline 6 & Ahmad Sauki & 4 & 4 & 3 & 4 & 5 & 5 & 4 & 4 & 4 & & \\
\hline & Profile & 4 & 4 & 4 & 4 & 4 & 4 & 4 & 4 & 4 & $(+)$ & ) \\
\hline 1 & Ahamd Fauzi & 0 & 0 & 1 & 1 & -1 & -1 & 0 & 0 & -1 & 2 & -2 \\
\hline 2 & Bambang Eb & 0 & 0 & 1 & 1 & -1 & -1 & 1 & 0 & 1 & 4 & -2 \\
\hline 3 & $\begin{array}{l}\text { Ahmad Nur } \\
\text { Sahid }\end{array}$ & 0 & 0 & 1 & 1 & -1 & 0 & 0 & 0 & -1 & 2 & -2 \\
\hline 4 & Adi Mulyono & 0 & -1 & -1 & 0 & 0 & 1 & 1 & 0 & 0 & -2 & 2 \\
\hline 5 & $\begin{array}{l}\text { Asep } \\
\text { Awaludin }\end{array}$ & 0 & 0 & 1 & 0 & 0 & -1 & -1 & -1 & 0 & 1 & -3 \\
\hline 6 & Ahmad Sauki & 0 & 0 & -1 & 0 & 1 & 1 & 0 & 0 & 0 & 2 & -1 \\
\hline
\end{tabular}

\section{Hasil dan Diskusi}

\subsection{Pemetaan GAP Kompetensi}

Tabel 2

Tabel Pemetaan Gap aspek kemampuan

1. Aspek Kemampuan

Tabel 3

Tabel Pemetaan Gap Kepribadian 


\begin{tabular}{|c|c|c|c|c|c|c|c|c|c|c|c|}
\hline \multirow[b]{2}{*}{ No. } & \multirow[b]{2}{*}{ Nama Salesman } & \multicolumn{10}{|c|}{ Variabel } \\
\hline & & K001 & K002 & K003 & K004 & K005 & K006 & K007 & K008 & \multicolumn{2}{|c|}{ GAP } \\
\hline 1 & Ahamd Fauzi & 3 & 4 & 4 & 4 & 5 & 5 & 5 & 5 & & \\
\hline 2 & Bambang Eb & 4 & 4 & 3 & 3 & 4 & 4 & 5 & 5 & & \\
\hline 3 & Ahmad Nur Sahid & 5 & 4 & 4 & 5 & 4 & 4 & 3 & 3 & & \\
\hline 4 & Adi Mulyono & 4 & 4 & 4 & 5 & 5 & 4 & 4 & 5 & & \\
\hline 5 & Asep Awaludin & 4 & 4 & 3 & 3 & 4 & 4 & 4 & 5 & & \\
\hline \multirow[t]{2}{*}{6} & Ahmad Sauki & 4 & 4 & 5 & 5 & 4 & 4 & 5 & 5 & & \\
\hline & Profile & 4 & 4 & 4 & 4 & 4 & 4 & 4 & 4 & $(+)$ & $(-)$ \\
\hline 1 & Ahamd Fauzi & -1 & 0 & 0 & 0 & 1 & 1 & 1 & 1 & 4 & -1 \\
\hline 2 & Bambang Eb & 0 & 0 & -1 & -1 & 0 & 0 & 1 & 1 & 2 & -2 \\
\hline 3 & Ahmad Nur Sahid & 1 & 0 & 0 & 1 & 0 & 0 & -1 & -1 & 2 & -2 \\
\hline 4 & Adi Mulyono & 0 & 0 & 0 & 1 & 1 & 0 & 0 & 1 & 3 & 0 \\
\hline 5 & Asep Awaludin & 0 & 0 & -1 & -1 & 0 & 0 & 0 & 1 & 1 & -2 \\
\hline 6 & Ahmad Sauki & 0 & 0 & 1 & 1 & 0 & 0 & 1 & 1 & 4 & 0 \\
\hline
\end{tabular}

2. Aspek Pengetahuan

Tabel 4

Tabel Pemetaan Gap Pengetahuan






\subsection{Penentuan Bobot Nilai GAP}

1. Aspek Kemampuan

Tabel 5

Tabel Bobot Gap aspek Kemampuan

\begin{tabular}{|c|c|c|c|c|c|c|c|c|c|c|}
\hline \multirow[b]{2}{*}{ No. } & \multirow[b]{2}{*}{ Nama Salesman } & \multicolumn{9}{|c|}{ Variabel } \\
\hline & & M001 & M002 & M003 & M004 & M005 & M006 & M007 & M008 & M009 \\
\hline 1 & Ahamd Fauzi & 0 & 0 & 1 & 1 & -1 & -1 & 0 & 0 & -1 \\
\hline 2 & Bambang Eb & 0 & 0 & 1 & 1 & -1 & -1 & 1 & 0 & 1 \\
\hline 3 & Ahmad Nur Sahid & 0 & 0 & 1 & 1 & -1 & 0 & 0 & 0 & -1 \\
\hline 4 & Adi Mulyono & 0 & -1 & -1 & 0 & 0 & 1 & 1 & 0 & 0 \\
\hline 5 & Asep Awaludin & 0 & 0 & 1 & 0 & 0 & -1 & -1 & -1 & 0 \\
\hline 6 & Ahmad Sauki & 0 & 0 & -1 & 0 & 1 & 1 & 0 & 0 & 0 \\
\hline \multicolumn{11}{|c|}{ Bobot } \\
\hline 1 & Ahamd Fauzi & 5 & 5 & 4.5 & 4.5 & 4 & 4 & 5 & 5 & 4 \\
\hline 2 & Bambang Eb & 5 & 5 & 4.5 & 4.5 & 4 & 4 & 4.5 & 5 & 4.5 \\
\hline 3 & Ahmad Nur Sahid & 5 & 5 & 4.5 & 4.5 & 4 & 5 & 5 & 5 & 4 \\
\hline 4 & Adi Mulyono & 5 & 4 & 4 & 5 & 5 & 4.5 & 4.5 & 5 & 5 \\
\hline 5 & Asep Awaludin & 5 & 5 & 4.5 & 5 & 5 & 4 & 4 & 4 & 5 \\
\hline 6 & Ahmad Sauki & 5 & 5 & 4 & 5 & 5 & 4.5 & 5 & 5 & 5 \\
\hline
\end{tabular}

2. Aspek Kepribadian

Tabel 6

Tabel Bobot Gap aspek Kepribadian

\begin{tabular}{|c|c|c|c|c|c|c|c|c|c|}
\hline \multirow[b]{2}{*}{ No. } & \multirow{2}{*}{$\begin{array}{c}\text { Nama } \\
\text { Salesman }\end{array}$} & \multicolumn{8}{|c|}{ Variabel } \\
\hline & & K001 & K002 & K003 & K004 & K005 & K006 & K007 & K008 \\
\hline 1 & $\begin{array}{l}\text { Ahamd } \\
\text { Fauzi }\end{array}$ & -1 & 0 & 0 & 0 & 1 & 1 & 1 & 1 \\
\hline 2 & $\begin{array}{l}\text { Bambang } \\
\mathrm{Eb}\end{array}$ & 0 & 0 & -1 & -1 & 0 & 0 & 1 & 1 \\
\hline 3 & $\begin{array}{l}\text { Ahmad Nur } \\
\text { Sahid }\end{array}$ & 1 & 0 & 0 & 1 & 0 & 0 & -1 & -1 \\
\hline 4 & $\begin{array}{l}\text { Adi } \\
\text { Mulyono }\end{array}$ & 0 & 0 & 0 & 1 & 1 & 0 & 0 & 1 \\
\hline 5 & $\begin{array}{l}\text { Asep } \\
\text { Awaludin }\end{array}$ & 0 & 0 & -1 & -1 & 0 & 0 & 0 & 1 \\
\hline 6 & $\begin{array}{l}\text { Ahmad } \\
\text { Sauki }\end{array}$ & 0 & 0 & 1 & 1 & 0 & 0 & 1 & 1 \\
\hline \multicolumn{10}{|c|}{ Bobot } \\
\hline 1 & $\begin{array}{l}\text { Ahamd } \\
\text { Fauzi }\end{array}$ & 4 & 5 & 5 & 5 & 4.5 & 4.5 & 4.5 & 4.5 \\
\hline
\end{tabular}

3. Aspek Pengetahuan

Tabel 7

Tabel Bobot Gap aspek Pengetahuan

\begin{tabular}{|l|l|r|r|r|r|r|}
\hline & & \multicolumn{5}{|c|}{ Variabel } \\
\cline { 3 - 7 } No. & Nama Salesman & P001 & P002 & P003 & P004 & P005 \\
\hline 1 & Ahamd Fauzi & 0 & 0 & 1 & -1 & -1 \\
\hline 2 & Bambang Eb & 1 & 1 & 0 & 0 & -1 \\
\hline 3 & Ahmad Nur Sahid & -1 & -1 & 0 & 0 & 0 \\
\hline 4 & Adi Mulyono & 0 & 0 & 1 & 1 & 0 \\
\hline
\end{tabular}




\begin{tabular}{|l|l|r|r|r|r|r|r|}
\cline { 2 - 7 } 5 & Asep Awaludin & 0 & 0 & 0 & 1 & 0 \\
\hline 6 & Ahmad Sauki & -1 & 0 & 0 & 1 & 0 \\
\hline \multicolumn{7}{|c|}{ BOBOT } \\
\hline 1 & Ahamd Fauzi & 5 & 5 & 4.5 & 4 & 4 \\
\hline 2 & Bambang Eb & 4.5 & 4.5 & 5 & 5 & 4 \\
\hline 3 & Ahmad Nur Sahid & 4 & 4 & 5 & 5 & 5 \\
\hline 4 & Adi Mulyono & 5 & 5 & 4.5 & 4.5 & 5 \\
\hline 5 & Asep Awaludin & 5 & 5 & 5 & 4.5 & 5 \\
\hline 6 & Ahmad Sauki & 4 & 5 & 5 & 4.5 & 5 \\
\hline
\end{tabular}

\subsection{Perhitungan dan Pengelompokan Core Factor dan Secondary Factor}

1. Aspek Kemampuan

Setelah Menentukan bobot nilai gap untuk setiap aspek pada penilaian predikat salesman, kemudian setiap aspek dibagi menjadi dua yaitu core factor dan secondary factor. Core factor didapat dari $5 \mathrm{sub}$ kriteria utama, yaitu M001, M002, M003, M004,
M005. Dan Secondary factor didapat 4 sub kriteria, yaitu M006, M007, M008, M009. Kemudian nilai core factor dan secondary factor tersebut dijumlahkan sesuai rumus dan hasilnya bisa dilihat ditabel

Tabel 8

Nilai CF dan SF Aspek Kemampuan Salesman

\begin{tabular}{|c|c|c|c|c|c|c|c|c|c|c|c|c|}
\hline \multirow[b]{2}{*}{ No. } & \multirow{2}{*}{$\begin{array}{c}\text { Nama } \\
\text { Salesman }\end{array}$} & \multicolumn{11}{|c|}{ Variabel } \\
\hline & & M001 & M002 & M003 & M004 & M005 & M006 & M007 & M008 & M009 & $\mathrm{CF}$ & SF \\
\hline 1 & Ahamd Fauzi & 5 & 5 & 4.5 & 4.5 & 4 & 4 & 5 & 5 & 4 & 4.6 & 4.5 \\
\hline 2 & Bambang Eb & 5 & 5 & 4.5 & 4.5 & 4 & 4 & 4.5 & 5 & 4.5 & 4.6 & 4.5 \\
\hline 3 & $\begin{array}{l}\text { Ahmad Nur } \\
\text { Sahid }\end{array}$ & 5 & 5 & 4.5 & 4.5 & 4 & 5 & 5 & 5 & 4 & 4.6 & 4.8 \\
\hline 4 & Adi Mulyono & 5 & 4 & 4 & 5 & 5 & 4.5 & 4.5 & 5 & 5 & 4.6 & 4.8 \\
\hline 5 & $\begin{array}{l}\text { Asep } \\
\text { Awaludin }\end{array}$ & 5 & 5 & 4.5 & 5 & 5 & 4 & 4 & 4 & 5 & 4.9 & 4.3 \\
\hline 6 & Ahmad Sauki & 5 & 5 & 4 & 5 & 5 & 4.5 & 5 & 5 & 5 & 4.8 & 4.9 \\
\hline
\end{tabular}

2. Aspek Kepribadian

Setelah Menentukan bobot nilai gap untuk setiap aspek pada penilaian predikat salesman, kemudian setiap aspek dibagi menjadi dua yaitu core factor dan secondary factor. Core factor didapat dari 5 sub kriteria utama, yaitu K001, K002, K003, K004, K005. Dan Secondary factor didapat 3 sub kriteria, yaitu K006, K007, K008. Kemudian nilai core factor dan secondary factor tersebut dijumlahkan sesuai rumus dan hasilnya bisa dilihat ditabel, berikut cara pengerjaannya :

Tabel 9

Nilai CF dan SF Aspek Kepribadian Salesman

\begin{tabular}{|c|c|c|c|c|c|c|c|c|c|c|c|}
\hline \multirow[b]{2}{*}{ No. } & \multirow{2}{*}{$\begin{array}{c}\text { Nama } \\
\text { Salesman } \\
\end{array}$} & \multicolumn{10}{|c|}{ Variabel } \\
\hline & & K001 & K002 & K003 & K004 & K005 & K006 & K007 & K008 & $\mathrm{CF}$ & SF \\
\hline 1 & Ahamd Fauzi & 4 & 5 & 5 & 5 & 4.5 & 4.5 & 4.5 & 4.5 & 4.7 & 4.5 \\
\hline 2 & Bambang Eb & 5 & 5 & 4 & 4 & 5 & 5 & 4.5 & 4.5 & 4.6 & 4.7 \\
\hline 3 & $\begin{array}{l}\text { Ahmad Nur } \\
\text { Sahid }\end{array}$ & 4.5 & 5 & 5 & 4.5 & 5 & 5 & 4 & 4 & 4.8 & 4.3 \\
\hline 4 & Adi Mulyono & 5 & 5 & 5 & 4.5 & 4.5 & 5 & 5 & 4.5 & 4.8 & 4.8 \\
\hline 5 & $\begin{array}{l}\text { Asep } \\
\text { Awaludin }\end{array}$ & 5 & 5 & 4 & 4 & 5 & 5 & 5 & 4.5 & 4.6 & 4.8 \\
\hline
\end{tabular}




\begin{tabular}{|l|l|l|l|l|l|l|l|l|l|l|l|}
6 & Ahmad Sauki & 5 & 5 & 4.5 & 4.5 & 5 & 5 & 4.5 & 4.5 & 4.8 & 4.7 \\
\hline
\end{tabular}

3. Aspek Pengetahuan

Setelah Menentukan bobot nilai gap untuk setiap aspek pada penilaian predikat salesman, kemudian setiap aspek dibagi menjadi dua yaitu core factor dan secondary factor. Core factor didapat dari 3 sub kriteria utama, yaitu P001, P002, P003. Dan Secondary factor didapat 2 sub kriteria, yaitu P004, P005. Kemudian nilai core factor dan secondary factor tersebut dijumlahkan sesuai rumus dan hasilnya bisa dilihat ditabel, berikut cara pengerjaannya :

Tabel 10

Nilai CF dan SF Aspek Pengetahuan

\begin{tabular}{|c|c|c|c|c|c|c|c|c|}
\hline \multirow[b]{2}{*}{ No. } & \multirow[b]{2}{*}{ Nama Salesman } & \multicolumn{7}{|c|}{ Variabel } \\
\hline & & P001 & P002 & P003 & P004 & P005 & $\mathrm{CF}$ & SF \\
\hline 1 & Ahamd Fauzi & 5 & 5 & 4.5 & 4 & 4 & 4.8 & 4 \\
\hline 2 & Bambang Eb & 4.5 & 4.5 & 5 & 5 & 4 & 4.7 & 4.5 \\
\hline 3 & Ahmad Nur Sahid & 4 & 4 & 5 & 5 & 5 & 4.3 & 5 \\
\hline 4 & Adi Mulyono & 5 & 5 & 4.5 & 4.5 & 5 & 4.8 & 4.8 \\
\hline 5 & Asep Awaludin & 5 & 5 & 5 & 4.5 & 5 & 5 & 4.8 \\
\hline 6 & Ahmad Sauki & 4 & 5 & 5 & 4.5 & 5 & 4.7 & 4.8 \\
\hline
\end{tabular}

\subsection{Perhitungan Nilai Total}

Hasil perhitungan Kapasitas dibawah ini merupakan analisa dari 5 responden dengan presentase bobot pengambilan keputusan antara lain Felix (30\%), Charlos (15\%), Aprillia (15\%). Erwin (20\%), Anthony (20\%) dalam menentukkan predikat Salesman Terbaik.

1. Kapasitas Kemampuan Salesman
a. Ahmad Fauzi $=(30 \% \quad \mathrm{x}$ 4.6) $+(15 \% \quad \mathrm{x}$ $4.6)+(15 \% \quad \mathrm{x} \quad 4.732)+(20 \% \quad \mathrm{x} \quad 4.59)+(20 \%$ $\mathrm{x} 4.56)=4.61$
b. Bambang $\mathrm{Eb}=(30 \% \quad \mathrm{x} \quad 4.6)+(15 \% \quad \mathrm{x}$ $4.66)+(15 \% \quad x \quad 4.16)+(20 \% \quad x \quad 4.24)+(20 \%$ $\mathrm{x} 4.56)=4.46$

c. Ahmad Nur Sahid $=(30 \%$ x 4.7$)+(15 \% \times$ $4.58)+(15 \% \times$ x 4.212) $+(20 \% \times 4.44)+(20 \%$ $\mathrm{x} 4.48)=4.51$

d. Adi Mulyono $=\left(\begin{array}{lll}30 \% & \mathrm{x} & 4.7\end{array}\right)+(15 \% \mathrm{x}$ $4.78)+(15 \% \quad x \quad 4.66)+(20 \% \quad x \quad 4.44)+(20 \%$ $\mathrm{x} 4.44)=4.6$

e. Asep Awaludin $=(30 \% \quad x \quad 4.7)+(15 \% \quad x$ $4.89)+(15 \% \times 4.78)+(20 \% \times 4.88)+(20 \% \times 4.6)$ $=4.76$

f. Ahmad Sauki $=(30 \% \quad \mathrm{x} \quad 4.8)+(15 \% \quad \mathrm{x}$ $4.58)+(15 \% \quad \mathrm{x} \quad 4.38)+(20 \% \quad \mathrm{x} \quad 4.68)+(20 \%$ $\mathrm{x} 4.32)=4.5$

Tabel 11

Hasil Akhir Nilai Total Aspek Kemampuan Salesman

\begin{tabular}{|c|c|c|c|c|c|c|}
\hline \multirow{2}{*}{$\begin{array}{c}\text { Aspek } \\
\text { kemampuan }\end{array}$} & \multicolumn{5}{|c|}{ Presentase penilaian $(\%)$} & \multirow[b]{2}{*}{$\mathrm{NT}(\mathrm{km})$} \\
\hline & Felix & Charlos & Aprillia & Erwin & Anthony & \\
\hline Ahamd Fauzi & 4.6 & 4.6 & 4.732 & 4.59 & 4.56 & 4.61 \\
\hline Bambang Eb & 4.6 & 4.66 & 4.16 & 4.24 & 4.56 & 4.46 \\
\hline $\begin{array}{l}\text { Ahmad Nur } \\
\text { Sahid }\end{array}$ & 4.7 & 4.58 & 4.212 & 4.44 & 4.48 & 4.51 \\
\hline Adi Mulyono & 4.7 & 4.78 & 4.66 & 4.44 & 4.44 & 4.6 \\
\hline Asep Awaludin & 4.7 & 4.89 & 4.78 & 4.88 & 4.6 & 4.76 \\
\hline Ahmad Sauki & 4.8 & 4.58 & 4.38 & 4.68 & 4.32 & 4.58 \\
\hline
\end{tabular}

2. Kapasitas Kepribadian Salesman
a. Ahmad Fauzi $=(30 \% \quad \mathrm{x}$ 4.6) $+(15 \% \mathrm{x}$ $4.64)+(15 \% \times 4.252)+(20 \% \times 4.612)+(20 \%$ $\mathrm{x} 4.54)=4.54$

b. Bambang $\mathrm{Eb}=(30 \% \quad \mathrm{x} \quad 4.6)+(15 \% \quad \mathrm{x}$ $4.43)+(15 \% \times 4.43)+(20 \% \times$ x 4.368$)+(20 \%$ $\mathrm{x} 4.572)=4.5$ 
c. Ahmad Nur Sahid $=(30 \% \mathrm{x}$ 4.6) $+(15 \% \mathrm{x}$ $4.75)+(15 \% \times 4.75)+(20 \% \times 4.628)+(20 \%$ $\mathrm{x} 4.64)=4.66$

d. Adi Mulyono $=(30 \% \quad \mathrm{x} \quad 4.8)+(15 \% \quad \mathrm{x}$ $4.63)+(15 \% \times 4.63)+(20 \% \times 4.492)+(20 \%$ $\mathrm{x} 4.492)=4.63$ e. Asep Awaludin $=(30 \%$ x 4.7) $+(15 \% \quad x$ $4.74)+(15 \% \quad x \quad 4.74)+(20 \% \quad x \quad 4.36)+(20 \%$ $\mathrm{x} 4.748)=4.65$

f. Ahmad Sauki $=(30 \% \quad \mathrm{x}$ 4.8) $+(15 \% \quad \mathrm{x}$ $4.75)+(15 \%$ x 4.75$)+(20 \% \quad x \quad 4.68)+(20 \%$ $\mathrm{x} 4.678)=4.74$

Tabel 12

Hasil Akhir Nilai Total Kepribadian Salesman

\begin{tabular}{|l|c|c|c|c|c|c|}
\hline \multirow{2}{*}{$\begin{array}{c}\text { Aspek } \\
\text { kepribdian }\end{array}$} & \multicolumn{7}{|c|}{ Presentase penilaian (\%) } \\
\cline { 2 - 7 } & Felix & Charlos & Aprillia & Erwin & Anthony & NT(kk) \\
\hline Ahamd Fauzi & 4.6 & 4.64 & 4.64 & 4.252 & 4.612 & 4.54 \\
\hline Bambang Eb & 4.6 & 4.43 & 4.43 & 4.368 & 4.572 & 4.5 \\
\hline $\begin{array}{l}\text { Ahmad Nur } \\
\text { Sahid }\end{array}$ & 4.6 & 4.75 & 4.75 & 4.628 & 4.64 & 4.66 \\
\hline Adi Mulyono & 4.8 & 4.63 & 4.63 & 4.492 & 4.492 & 4.63 \\
\hline Asep Awaludin & 4.7 & 4.74 & 4.74 & 4.36 & 4.748 & 4.65 \\
\hline Ahmad Sauki & 4.8 & 4.75 & 4.75 & 4.68 & 4.678 & 4.74 \\
\hline
\end{tabular}

3. Kapasitas Pengetahuan Salesman

Tabel 13

Hasil Akhir Nilai Total Pengetahuan Salesman

\begin{tabular}{|l|c|c|c|c|c|c|}
\hline \multirow{2}{*}{ Aspek penegetahuan } & \multicolumn{7}{|c|}{ Presentase penilaian (\%) } \\
\cline { 2 - 7 } & Felix & Charlos & Aprillia & Erwin & Anthony & NT(kp) \\
\hline Ahamd Fauzi & 4.5 & 4.9 & 4.7 & 4.602 & 4.602 & 4.631 \\
\hline Bambang Eb & & & & & & \\
\hline Ahmad Nur Sahid & 4.6 & 4.9 & 4.698 & 4.7 & 4.602 & 4.68 \\
\hline Adi Mulyono & 4.8 & 4.5 & 4.602 & 4.598 & 4.802 & 4.685 \\
\hline Asep Awaludin & 4.9 & 4.6 & 4.502 & 4.802 & 4.802 & 4.756 \\
\hline Ahmad Sauki & 4.7 & 4.7 & 4.702 & 4.798 & 4.698 & 4.72 \\
\hline
\end{tabular}

\subsection{Perhitungan Penentuan Ranking}

Penentuan ranking dalam proses profile matching pada Penilaian Predikat Salesman Terbaik merupakan hasil akhir. Berikut ini adalah perhitungan penentuan ranking Salesman Terbaik :

1. Ahmad Fauzi $=(40 \% \times 4.61)+(30 \% \times 4,59)+$ $(30 \% \times 4.63)=4,61$

2. Bambang $\mathrm{EB}=(40 \% \times 4.46)+(30 \% \times 4,5)+$ $(30 \% \times 4.68)=4,538$
3. Ahmad Nur Sahid $=(40 \% \times 4.51)+(30 \% \times 4,66)$ $+(30 \% \times 4.56)=4,57$

4. Adi Mulyono $=(40 \% \times 4.6)+(30 \% \times 4,63)+$ $(30 \% \times 4.69)=4,636$

5. Asep Awaludin $=(40 \% \times 4.76)+(30 \% \times 4,65)+$ $(30 \% \times 4.76)=4,727$

6. Ahmad Sauki $=(40 \% \times 4.58)+(30 \% \times 4,74)+$ $(30 \% \times 4.72=4,67$

Tabel 14

Tabel Skor/ Rangking Salesman Terbaik

\begin{tabular}{|l|c|c|c|c|c|}
\hline Nama Salesman & NT(km) & NT(kk) & NT(kp) & SKOR & RANGKING \\
\hline Ahamd Fauzi & 4.61 & 4.59 & 4.63 & 4.61 & 4 \\
\hline Bambang Eb & 4.46 & 4.5 & 4.68 & 4.538 & 6 \\
\hline $\begin{array}{l}\text { Ahmad Nur } \\
\text { Sahid }\end{array}$ & 4.51 & 4.66 & 4.56 & 4.57 & 5 \\
\hline Adi Mulyono & 4.6 & 4.63 & 4.69 & 4.636 & 3 \\
\hline Asep Awaludin & 4.76 & 4.65 & 4.76 & 4.727 & 1 \\
\hline Ahmad Sauki & 4.58 & 4.74 & 4.72 & 4.67 & 2 \\
\hline
\end{tabular}

142 | http://www.jurnal.umb.ac.id/index.php/JSAI 


\section{Hasil Penelitian}

Hasil terakhir dari penelitian ini yaitu terpilihnya 6 kandidat dalam penilaian Salesman Terbaik, Di peringkat 6 ditempati oleh Bambang Eb, di peringkat 5 oleh Ahmad Nur Sahid, di peringkat 4 oleh Ahmad Fauzi, di peringkat 3 oleh Adi Mulyono, di peringkat 2 oleh Ahmad Sauki, dan di peringkat pertama atau teratas dengan nilai Aspek Kemampuan sebesar 4.76, Aspek Kepribadian sebesar 4.65, dan Aspek Pengetahuan sebesar 4.75 ditempati oleh Asep Awaludin yang terpilih sebagai Salesman Terbaik.

\section{Kesimpulan Dan Saran}

Berdasarkan maksud, tujuan, pengolahan data dan analisa yang telah dilakukan oleh penulis menarik kesimpulan bahwa setiap aspek atau kriteria penilaian salesman sangat berpengaruh dalam proses pemilihan Salesman Terbaik, kriteria-kriteria dalam perhitungan tersebut membuat penilaian yang dilakukan lebih objektif. Aspek-aspek disini meliputi Kemampuan, Kepribadian, serta Pengetahuan Salesman. Selain itu perhitungan yang dilakukan lebih akurat karena menggunakan Metode Profile Matching, dengan pembobotan dan perangkingan nilai di dalamnya. Dan hasil akhir dari penilitian ini dapat dijadikan acuan oleh Sales Manager dalam menentukan Salesman Terbaik.

Saran terhadap penelitian mengenai sistem pendukung keputusan penilaian Predikat Salesman Terbaik Pada PT. Arta Boga Cemrlang Jakarta dengan metode profile matching. Terbagi kedalam tiga aspek yaitu :

1. Aspek Manajerial

PT. Arta Boga Cemerlang diharapkan lebih memonitoring Performance Salesman, karena dapat memberikan penilaian terhadap Salesman lebih tepat dengan kriteria-kriteria yang sesuai dengan standar perusahaan yang digunakan sebagai pemilihan Predikat Salesman Terbaik

2. Aspek Sistem
Untuk kedepannya diharapkan dibuatkan rancangan aplikasi sistem pendukung keputusan dalam menentukan Salesman Terbaik, sehingga dapat memudahkan bagian Sales Manager dalam melakukan penilaian. Selain itu dapat mengurangi terjadinya kesenjangan diantara sesama Salesman dalam hal pemilihan Salesman Terbaik.

3. Aspek Penelitian

Penelitian selanjutnya diharapkan dengan menambah sub-kriteria dan penyesuaian nilai profile karyawan yang dibutuhkan sesuai dengan kebutuhan perusahaan. Sehingga menghasilkan penelitian yang lebih baik, dalam hal kualitas data penelitian yang akan diolah dan dianalisis.

\section{Referensi}

[1] E. Sutinah, "Sistem Pendukung Keputusan Menggunakan Metode Profile Matching Dalam Pemilihan Salesman Terbaik," INFORMATICS Educ. Prof., vol. 2 no 1, pp. 29-42, 2017.

[2] A. Setiawan, Sutardi, and L. Tajidun, "Spk Penilaian Dan Pemberian Bonus Salesman Pada Pt Matakar Kendari Dengan Menggunakan Metode Profile Matching," semanTIK, vol. Vol 3 No 1, pp. 199-208, 2017.

[3] Z. Hakim, A. Sudiarjo, and R. Efrida, "Rancangan Sistem Penunjang Keputusan Pengangkatan Karyawan Tetap Dengan Metode Profile Matching di PT. Lotte Packaging," $J$. SISFOTEK Glob., vol. 7 n.o2, pp. 13-19, 2017.

[4] Khoirun Nisa and E. Sutinah, "Profile Matching Untuk Sistem Pendukung Keputusan Pemilihan Vendor Maintenance Server dan Jaringan," J. Inform., vol. Vol 5 No2, pp. 262-269, 2017.

[5] Kusrini, Konsep Aplikasi Sistem Pendukung Keputusan. Jakarta: Andi Offset., 2007. 